\title{
TEP1 Gene
}

National Cancer Institute

\section{Source}

National Cancer Institute. TEP1 Gene. NCI Thesaurus. Code C20208.

This gene plays a role in telomerase activity. 